Niepełnosprawność. Dyskursy pedagogiki specjalnej

Nr 31/2018

Disability. Discourses of special education

No. $31 / 2018$

Agnieszka Nymś-Górna

Uniwersytet im. Adama Mickiewicza w Poznaniu

\title{
Problematyka seksualności osób z niepełnosprawnością intelektualną
}

Jednym z kluczowych aspektów życia człowieka jest jego seksualność. Jest ona nieodłącznym elementem każdej istoty ludzkiej. Każdy ma prawo spełniać się w zakresie swojej intymności. Problematyka ta nie jest łatwa, gdyż łączy się z bardzo delikatną sferą egzystencji. Niemniej jedmak wiele $\mathrm{w}$ tym zakresie można zrobić za pośrednictwem odpowiedniej edukacji. Temat ten nie może stanowić swego rodzaju tabu także w kontekście osób z niepełnosprawnością.

Słowa kluczowe: intymność, seksualność, niepełnosprawność

\section{Problems of sexuality of people with intellectual disabilities}

One of the keyaspects of a human's life ishissexuality. It isaninseparable element of everyhumanbeing. Everyonehas the right to fulfilltheirintimacy. This problem is not easy, becauseitconnects with a verydelicatesphere of existence. Nevertheless, a lot can be done in thisareathroughappropriateeducation. Thissubjectcan not be a kind of tabooalso in the context of people with disabilities.

Keywords: intimacy, sexuality, disability

\section{Wprowadzenie}

Niewątpliwie jedną z najbardziej „przemilczanych” sfer życia człowieka jest jego seksualność. Owe „przemilczanie” jest jednak na swój sposób paradoksalne, bowiem z jednej strony erotyka jest w rozmaitych przekazach wręcz nadreprezentowana, jednak $\mathrm{z}$ drugiej strony $\mathrm{w}$ aspekcie popularyzowania rzetelnej wiedzy, seksualność człowieka jest już tematem poruszanym dużo mniej chętnie. W niektórych przypadkach zagadnienie to stanowi wręcz swoiste tabu w klasycznym rozumieniu. Tak dzieje się w przypadku, gdy mowa o seksualności osób z niepełnosprawnością (zwłaszcza niepełnosprawnością intelektualną). U wspomnianych osób niestety nierzadko seksualność traktuje się w kategoriach czegoś, co nie powinno mieć miejsca z uwagi na dysfunkcje danej osoby.Z uwagi na fakt, 
że każda niepełnosprawność wyróżnia się pewnymi specyficznymi cechami oraz zachowaniami, w tym tekście zostanie omówiona przede wszystkim specyfika funkcjonowania osób z niepełnosprawnością intelektualną. Jest to temat tym bardziej istotny, że najnowsze badania realizowane w Polsce dowiodły, iż osoby z niepełnosprawnością intelektualną wchodzą w związki oraz wykazują potrzebę bliskości intymnej (Kijak 2016).

Niemniej jednak myślenie stereotypowe wynika bez wątpienia z niewłaściwej edukacji osób powielających tego typu schematy myślenia. Seksualność jest bowiem integralną częścią każdej kobiety i każdego mężczyzny - bez względu na posiadaną (bądź nieposiadaną) niepełnosprawność. Jak wspomina J.A. Kowalski:

Seksem musiał się człowiek interesować naprawdę od początku, podobnie jak pożywieniem, ponieważ inaczej nie bytoby nas na tym świecie [Kowalski 2011: 9].

Słowa te świadczą o tym jak istotna jest to kwestia dla każdego człowieka, bowiem prokreacja, podobnie jak potrzeba zdobycia pożywienia przypisana jest w sposób nieodłączny do naturalnych mechanizmów funkcjonowania - nie tylko w wymiarze jednostkowym, ale także w aspekcie społecznym. Treść niniejszego artykułu koncentrować się będzie w głównej mierze na zagadnieniu seksualności osób z niepełnosprawnością intelektualną.

\section{Sposoby rozumienia seksualności i płciowości}

Kwestią elementarną w kontekście podjęcia powyższego tematu jest uściślenie znaczenia samej seksualności. Zdaniem M. Laphomon'a stanowi ona podstawowy element człowieczeństwa, który obejmuje zarówno prokreację, intymność, pożądanie, erotyzm, orientację seksualną, rolę i identyfikację płciową, jak również sam seks. W swojej definicji wyraża mniemanie, iż:

Seksualność jest doświadczana i wyrażana w myślach, fantazjach, przeżyciach, przekonaniach, wartościach, zachowaniach, rolach i związkach. Seksualność powstaje na skutek interakcjiczynników biologicznych, psychologicznych, społecznych, ekonomicznych, politycznych, kulturowych, etycznych, prawnych, historycznych, religijnych i duchowych [Kamińska, Kierzkowski 2016: 332].

Przytoczona definicja w sposób jednoznaczny ukazuje fakt, iż seksualność powiązana jest nie tylko z rozwojem biologicznym człowieka, lecz także ściśle dotyczy sfery psychicznej i wiąże się z codziennym funkcjonowaniem człowieka. Światowa Organizacja Zdrowia także dostrzegła niebywałą istotność zagadnienia seksualności człowieka, przyjmując w 2002 r. Deklarację Praw Seksualnych Człowie$k a$. W treści przytoczonej deklaracji podkreśla się, iż pełen rozwój seksualności ko- 
nieczny jest do osiągnięcia szeroko pojmowanego dobrostanu w każdym wymiarze ludzkiego życia (Deklaracja Praw Seksualnych Człowieka, dostęp online).

$\mathrm{W}$ aspekcie niniejszych rozważań niezwykle ważne jest uściślenie pojęcia płciowości, samej płci, a także zdrowia seksualnego. Termin zdrowia seksualnego jest natomiast przyjęty przez wspomnianą wcześniej Światową Organizację Zdrowia. Oznacza zintegrowaną współegzystencję czynników emocjonalnych, biologicznych, intelektualnych oraz społecznych $\mathrm{w}$ obrębie życia seksualnego [Aouil 2010: 80]. Celem tej koncepcji jest podkreślenie wagi wykształconej seksualności dla całościowego rozwoju człowieka, w tym jego relacji interpersonalnych. Z zagadnieniem tym w sposób bezpośredni łączy się także kwestia prokreacji oraz prawa kobiet i mężczyzn do odpowiedniej wiedzy oraz metod planowania rodziny. Istotne jest, aby były one skuteczne, bezpieczne, przystępne pod względem finansowym oraz akceptowalne etycznie [Kamińska, Kierzkowski 2016: 332].

Istotnym pojęciem jest także płeć oraz płciowość. Według Słownika Języka Polskiego płeć to „zespół właściwości charakteryzujących organizmy osobników męskich i żeńskich iprzeciwstawiających je sobie wzajemnie" [Szymczak 1992: 698]. Zatem płciowość człowieka jest pojęciem dużo szerszym i rozumiana jest jako obszar życia człowieka definiującym własne życie jako kobieta, bądź jako mężczyzna.

Ptciowość jest złożona i integrująca siła osoby ludzkiej, z której wyrasta istnienie i działanie osoby określające jej sposób bycia jako mężczyzny lub kobiety; oraz sposób działania i reagowania jako mężczyzny lub kobiet [Bołoz 2003: 19].

Powyższa definicja pojmuje zatem płciowość człowieka bardziej przez prymat czynników kulturowych, społecznych i psychologicznych, aniżeli stricte biologicznych. Warto podkreślić także fakt, iż płciowość istnieje tak naprawdę zupełnie niezależnie od występowania (lub nie) jakiejkolwiek niepełnosprawności u konkretnej osoby. Warto dodać, że jak wynika z badań, osoby z niepełnosprawnością intelektualną, znają określenia płci, identyfikują się ze swoją płcią i potrafią wskazać różnice między płciami [Otrębski, Czusz 2013: 233].

W wielu przypadkach seksualność osób z niepełnosprawnością intelektualną (zwłaszcza w stopniu lekkim) jest zupełnie normalna i nie wymaga jakiejkolwiek interwencji (poza rzetelną i dostosowaną do możliwości danej osoby edukacją seksualną), natomiast niemal wszystkie te osoby posiadają potrzeby seksualne i w rozmaity sposób dążą do ich spełnienia. Akceptowalność form wspomnianego dążenia powiązana jest również z zagadnieniem stosownej edukacji. Edukacja seksualna z kolei w dużej mierze opiera się na publikacjach (również naukowych) z danej dziedziny. R. Kijak zwraca zatem uwagę na to, że w publikacjach pomija się kwestię antykoncepcji, opieki ginekologicznej, czy przemocy seksualnej wobec osób z niepełnosprawnością [Kijak 2013: 14-15]. Tym bardziej istotne jest porusza- 
nie tak ważnych (a wciąż uważanych za trudnych) tematów podczas rozmów z osobami z niepełnosprawnością.

\section{Specyfika seksualności osób z niepełnosprawnością intelektualną}

Jak zauważa K. Imieliński, z zaburzeniami seksualnymi mamy do czynienia, gdy owa wrodzona funkcja ulegnie zniekształceniu lub zahamowaniu, bądź będzie istnieć w skrajnej dysharmonii w odniesieniu do innych aspektów osobowości człowieka [Imieliński 1986: 26]. M. Kościelska zauważa natomiast, że u osób z niepełnosprawnością intelektualną często występują przejawy tzw.,,spóźnionej dziecięcej seksualności", na którą składa się [Kościelska 2004: 44-51]:

1) dążenie do bliskości z matką;

2) chwiejność nastroju uzależniona od zachowania najbliższej osoby;

3) poszukiwanie kontaktu fizycznego z bliską osobą poprzez przytulanie, bądź całowanie;

4) obnażanie się;

5) domaganie się od bliskich dowodów miłości;

6) brak zachowania strefy intymnej z osobami świeżo zapoznanymi (ich ściskanie i całowanie).

Osoby z niepełnosprawnością intelektualną zwłaszcza w okresie dojrzewania (podobnie jak ich zdrowi rówieśnicy) zmagają się z wysokim skokiem hormonalnym. Mają zatem takie same potrzeby i bardzo podobne problemy jak inne nastolatki, lecz niezwykle trudno jest im sobie z nimi poradzić.

W aspekcie zachowań seksualnych osób z niepełnosprawnością intelektualną zdecydowanie dominuje masturbacja, jednak w literaturze wyróżnia się w tym kontekście rozmaite jej rodzaje [Kościelska 2004: 44-51]:

1) Masturbacja jako wyładowanie epileptyczne - występuje wyłącznie u osób z uszkodzonym układem nerwowym. Prawidłowa czynność mózgu zostaje wówczas zakłócona, a podwzgórze wywołuje wyładowania epileptyczne, podczas których można zaobserwować napad padaczkowy, a wraz z nim osoba z niepełnosprawnością wykonuje ruchy kopulacyjne. Warto jednak podkreślić, iż diagnozę masturbacji epileptycznej można potwierdzić wyłącznie podczas badania EEG.

2) Masturbacja nerwicowa - ten rodzaj masturbacji zauważalny jest u osób z niepełnosprawnością intelektualną, które doświadczają silnego lęku. W tym przypadku masturbacja może służyć redukcji napięcia psychicznego oraz lęku. Taki rodzaj masturbacji jest szczególnie destrukcyjny dla zdrowia seksualnego danej osoby. 
3) Masturbacja jako instrument redukcji napięcia mięśniowego - szczególnie często występuje u osób z autyzmem. Osoby te dysponują bardzo ograniczonym repertuarem wyrażania rozmaitych emocji, których nie mogą wyrazić poprzez płacz lub śmiech, zatem powstałe napięcie mięśniowe próbują redukować za pomocą poruszania rękoma, podskakiwania, masturbowania się lub wykonywania ruchów kopulacyjnych.

4) Masturbacja jako efekt monotonii - osoby z niepełnosprawnością intelektualną nierzadko mają niestety ograniczoną możliwość spędzania wolnego czasu, a proponowane przez opiekunów zajęcia często nie są dla nich wystarczająco interesujące. $\mathrm{Z}$ tego powodu masturbacja może być metodą autostymulacji i staje się metodą na spędzanie wolnego czasu.

5) Masturbacja prowokacyjna - $w$ tym przypadku zachowania masturbacyjne mają charakter publiczny, natomiast ich celem jest zdobycie uwagi innych osób. Przez niektóre osoby może być mylnie postrzegana jako ekshibicjonizm. Do problemów seksualnych osób z niepełnosprawnością intelektualną często zalicza się także rozerotyzowanie. Pojęcie to dotyczy tych osób, które inicjację seksualną mają już za sobą, znają już przyjemność, która wynika z odbywania stosunków seksualnych z drugą osobą. Osoby z niepełnosprawnością intelektualną mogą mieć problem, aby w odpowiedni sposób kontrolować potrzebę kolejnych zbliżeń intymnych [Kościelska 2004: 44-51]:

Niewątpliwie seksualność (a w szczególności kwestia rozpoczęcia życia seksualnego z innymi ludźmi) osób z niepełnosprawnością intelektualną stanowi bardzo poważny dylemat moralny dla rodziców i terapeutów. Z jednej strony istnieje bowiem pewne ryzyko, że osoby te nie będą $w$ stanie $w$ każdym przypadku w odpowiedni sposób użyć rozmaitych metod antykoncepcji i odebrać właściwej wiedzy na jej temat (jak również zagadnień dotyczących prokreacji). Równie problematyczne jest także zagadnienie tzw. „wydolności wychowawczej” osób dotkniętych niepełnosprawnością intelektualną - nie ma bowiem wątpliwości, że zadaniem niełatwym jest dla nich stworzenie kompleksowych warunków dla wszechstronnego rozwoju poczętego dziecka (szczególnie, gdy do poczęcia nie doszło na skutek świadomej decyzji).

Z drugiej strony jednak strony wiele osób (także ekspertów w dziedzinie seksualności osób z niepełnosprawnością intelektualną) uważa, że możliwość prowadzenia regularnego życia seksualnego z innymi osobami (oczywiście za obopólną zgodą tych osób) jest ich prawem, wynikającym z faktu posiadania seksualności przez każdą osobę. Podkreślają oni także, że nie jest regułą to, że dwoje osób z niepełnosprawnością intelektualną najczęściej płodzi dziecko z podobnymi dysfunkcjami.A. Midro podkreśla, że w całej światowej literaturze opisany jest tylko jeden przypadek urodzenia dziecka z tą samą przypadłością przez kobietę z zespołem Retta, natomiast we wszystkich innych przypadkach dzieci były jedy- 
nie nosicielami tej choroby [Kościelska 2004: 63]. Jest to oczywiście jeden z wielu przykładów, przytaczanych przez zwolenników prowadzenia aktywnego życia seksualnego przez osoby z niepełnosprawnością intelektualną, jednak należy pamiętać, iż w bardzo wielu przypadkach niepełnosprawności intelektualnej jest ona dziedziczna - niestety nie tylko w wymiarze samego nosicielstwa określonych jej przyczyn, lecz również ujawniania się wspomnianej niepełnosprawności.

\section{Osoby z niepełnosprawnością intelektualną a edukacja seksualna}

Zagadnieniem niezwykle istotnym w kontekście niniejszych rozważań jest niewątpliwie dostarczanie osobom z niepełnosprawnością intelektualną odpowiednich instrumentów do tego, aby potrafiły one w odpowiedni sposób definiować i rozumieć własną seksualność, jak również rozwijać kompetencje niezbędne do rozpoczęcia samodzielnego życia seksualnego. Do tego celu niezbędna jest oczywiście edukacja seksualna, jednak należy pamiętać, iż jej podstawową zasadą powinna być indywidualizacja, tj. dostosowanie przekazu do możliwości konkretnej osoby. Edukacja seksualna osób z niepełnosprawnością posiada jednak swoje jasno zdefiniowane cele, które poniżej zostaną wymienione i pokrótce scharakteryzowane [Parchomiuk 2009: 29-30].

1) Dostarczanie wiedzy i doświadczeń z zakresu płci - punkt ten zawiera w sobie edukację zarówno z zakresu pierwszo-, jak i drugorzędowych cech płciowych kobiet oraz mężczyzn, zagadnienia związane z poznaniem własnej cielesności, elementarne procesy fizjologiczne kobiet oraz mężczyzn, atrybuty definiujące kobiety oraz mężczyzn (jak również ich role społeczne), a także zagadnienie związane z poszanowaniem ciała drugiej osoby (szczególnie istotne $\mathrm{w}$ tym aspekcie jest odpowiednie rozróżnienie stref intymnych).

Aby zdobyć rzetelną wiedzę $\mathrm{w}$ tym zakresie niezbędne są; kontakt $\mathrm{z}$ osobami płci przeciwnej w różnym wieku, czynne uczestnictwo w aktywnościach codziennego życia, poznanie sposobów adekwatnego do płci i wieku ubierania się oraz czesania, podkreślanie atutów urody, przy jednoczesnym maskowaniu jej mankamentów oraz poznanie zróżnicowanych form spędzania czasu, dostosowanych do płci, wieku oraz indywidualnych upodobań.

2) Rozwijanie kompetencji i wiedzy z zakresu higieny oraz zdrowia - cel ten dotyczy głównie wiedzy z obszaru dbałości o higienę w zależności od płci, wieku, czy stanu zdrowia Do zagadnień związanych ze stanem zdrowia zalicza się w tym kontekście odżywianie czy higienę ciąży. Nie bez znaczenia w kontekście samej higieny jest natomiast dbałość o czystość ciała i otoczenia oraz odpowiednie ubranie. Istotna jest również higiena i bezpieczeństwo samego współży- 
cia seksualnego, jak również edukacja w zakresie akceptowalnych społecznie form rozładowywania napięcia seksualnego.

Niezbędne w celu zdobywania umiejętności w tym zakresie jest zachowanie samodzielności $w$ codziennym funkcjonowaniu $w$ środowisku, przy jednoczesnym zachowaniu jej adekwatności do możliwości oraz wieku osoby z niepełnosprawnością.

3) Formowanie się kompetencji z zakresu życia rodzinnego - na to zagadnienie składa się wiele zróżnicowanych czynników, począwszy od uczuciowych (takich jak miłość, czy przyjaźń), poprzez obyczajowe (takie jak życie w małżeństwie lub poza nim oraz wychowanie dziecka), a także stricte dotyczące zdrowia prokreacyjnego („techniczne" aspekty współżycia seksualnego, prokreacyjność człowieka oraz antykoncepcja).

Podobnie jak we wcześniejszych celach edukacyjnych bardzo ważnym warunkiem w kontekście realizacji formowania się kompetencji z zakresu życia rodzinnego będzie umożliwienie jak najpełniejszego uczestnictwa w nim osobom z niepełnosprawnością intelektualną lub (gdy nie jest to możliwe) tworzenie dla nich sposobności do zdobywania podobnych doświadczeń za pomocą kontaktów z rodzinami zaprzyjaźnionymi, bądź członkami dalszej rodziny.

4) Rozwijanie cech osobowości oraz nauka zaradności - przez tę kompetencję rozumie się naukę rozumienia emocji i uczuć (zarówno własnych, jak i innych osób), wyrażanie swoich uczuć, naukę asertywności i formułowanie własnego zdania, interpretowanie intencji innych osób, poznanie swoich negatywnych i pozytywnych stron, nauka poczucia odpowiedzialności za własną osobę i zachowanie, umiejętność podejmowania adekwatnych do sytuacji decyzji, naukę walki z negatywnymi doświadczeniami oraz skutecznego korzystania ze wsparcia innych osób.

Aby zrealizować powyższe treści należy stworzyć swoistą płaszczyznę do zdobywania osobistych doświadczeń $\mathrm{w}$ realiach codziennego funkcjonowania. Nie bez znaczenia jest także regularne dostrzeganie i wzmacnianie osiągnięć, rozjaśnianie wątpliwości na temat niepełnosprawności, wskazywanie na zachowania zgodne $\mathrm{z}$ oczekiwaniami społecznymi oraz udzielania wsparcia zarówno w codziennym życiu, jak i sytuacjach trudnych.

5) Przekazywanie wiedzy z zakresu przyjętych norm społecznego funkcjonowania, a także tworzenie sposobności do doświadczeń w tym zakresie. W tym punkcie najistotniejsze jest nauczenie danej osoby rozróżniania charakterystyki miejsc publicznych i prywatnych oraz tego, że charakter zachowań powinien uwarunkowany być przede wszystkim typem relacji (odpowiednio - neutralnym, przyjacielskim, koleżeńskim i intymnym). Istotne jest także wskazanie wzorów zachowań kulturalnych, jak również miejsc, w których niektóre zachowania (zwłaszcza o charakterze seksualnym) są sankcjonowane. 
Aby utrwalić odpowiednią wiedzę i zachowania z zakresu przytoczonego zagadnienia konieczne jest zapewnienie pełnej intymności codziennych czynności higienicznych w miejscu zamieszkania oraz zachowań seksualnych (np. masturbacji). Istotne jest również to, aby osoba z niepełnosprawnością intelektualną otrzymywała spójne informacje na temat powyższych kwestii z różnych źródeł (w szczególności od rodziców i nauczycieli). Nie bez znaczenia jest również obecność w miejscach publicznych (sklepy, instytucje usługowe, restauracje, instytucje kulturowe).

Połączenie profesjonalnej edukacji w powyższych aspektach z indywidualizacją stosowanych oddziaływań może (szczególnie w przypadku niepełnosprawności intelektualnej w stopniu lekkim) dać zaskakująco dobre efekty i w długofalowej perspektywie spowodować, że podopieczny będzie bardzo dobrze funkcjonować także w sferze kontaktów międzyludzkich (nawet w aspekcie tworzenia relacji o charakterze intymnym).

Niestety jednak - jak pokazują badania wśród rodziców dzieci z niepełnosprawnością intelektualną brakuje woli (lub czasami pewnej odwagi), by z dziećmi jakkolwiek podjać temat seksualności. Dodatkowo, szczególnie rzadko na temat seksualności rodzice rozmawiają z córkami (Gumienny 2016:109). Jest to szczególnie niepokojące, gdyż seksualność dziewcząt jest zagadnieniem dla nich szczególnie delikatnym - zwłaszcza w okresie dojrzewania ważne jest, aby miały one rzetelną (i przekazaną w sposób dla siebie przystępny) wiedzę na temat zmian, jakie zachodzą w ich ciałach - aby uniknąć sytuacji, w której normalne procesy zaczynają budzić poczucie lęku oraz wstydu.

\section{Zakończenie i wnioski}

Analizując zagadnienie seksualności osób z niepełnosprawnością warto zwrócić uwagę na kwestię krzywdzących stereotypów. Nawet media nierzadko prezentując takie osoby używają specyficznych obrazów, które przyczyniają się do powielania lęku, ciekawości (nierozumianej jednak jako pozytywna chęć osobistego poznania kogoś) i uprzedzenia. Zdarza się także, iż osoby z niepełnosprawnościami intelektualnymi przedstawiane są w sposób hiperpozytywny - uproszczenie to także może nie być korzystne dla tych osób, gdyż powoduje modelowanie nieadekwatnych i zbyt wygórowanych oczekiwań w społeczeństwie wobec tych osób (co może przyczyniać się do łatwiejszej ich krytyki oraz osądów kierowanych w ich stronę).

Również w aspekcie rozwoju seksualności osób z niepełnosprawnością intelektualną dominują dwa skrajnie różne stereotypy. Pierwszy z nich mówi o tym, że ludzie ci dotknięci są hiperseksualnością, co oznacza, że nie tylko nie są w stanie 
zapanować nad własnym popędem seksualnym, lecz również stanowią z tego powodu swoiste zagrożenie społeczne. Drugi traktuje natomiast o zupełnej aseksualności osób z niepełnosprawnością umysłową. Jest to stereotyp dla nich równie groźny, gdyż przyczynia się do opóźnienia osiągnięcia dojrzałości seksualnej (lub nawet całkowitego jej nieosiągnięcia), a także zahamowuje rozwój tożsamości płciowej, która niezwykle ważne jest dla samej tożsamości. Warto podkreślić, iż na wspomnianą tożsamość płciowa kształtowana jest między innymi poprzez społeczne oczekiwania wobec zachowań i cech wizualnych danej płci a także mechanizmu nagradzania elementów kobiecości u dziewcząt oraz męskości u chłopców [Karwacka 2006: 187-194].

Prawidłowy przebieg wymienionych powyżej mechanizmów kreowania się tożsamości (zwłaszcza płciowej) jest przez rozmaite stereotypy bardzo mocno zagrożony ze względu na postrzeganie tych osób poprzez pryzmat takich, których seksualność powinna budzić lęk (wówczas $\mathrm{w}$ wielu przypadkach podejmuje się niestety próby nawet farmakologicznego wygaszania popędu seksualnego) lub też jako "wieczne dzieci”, które nie mają potrzeb seksualnych (co również powoduje zatrzymanie się w rozwoju psychoseksualnym).

Podjęty w niniejszej pracy temat niewątpliwie należy do tych, które rozpatrywać należy w kategoriach najtrudniejszych dylematów nie tylko natury naukowej oraz etycznej, lecz także dotyczących codziennych wyborów rodziców, opiekunów i terapeutów osób z niepełnosprawnością intelektualną. Dodatkowo, omawiana kwestia komplikuje się na skutek faktu, iż dotyczy najintymniejszej i najbardziej delikatnej sfery człowieka - seksualności. Pomimo panowania rozmaitych poglądów na temat seksualności osób z niepełnosprawnością intelektualną warto podkreślić, że dostęp do rzetelnej (i dostosowanej do indywidualnych możliwości) edukacji seksualnej powinien stanowić ich niezbywalne prawo. Niezbędne jest też budowanie społecznej świadomości na omawiany temat, aby nieustannie podkreślać, iż seksualność u osób z niepełnosprawnością intelektualną nie jest dewiacją, lecz składa się z takich samych komponentów (w tym potrzeb), jak u ludzi zdrowych. Natomiast zrównoważony rozwój seksualności i możliwość posiadania poczucia spełnienia w tym aspekcie życia (bez ingerencji w wolność drugiej osoby) powinny być prawem każdego człowieka, niezależnie od stanu jego zdrowia.

\section{Bibliografia}

Aouil B. (2010), Kinezyterapeutyczne metody w rehabilitacji seksualnej osób niepełnosprawnych, „Przegląd Terapeutyczny”, nr 8.

Bołoz W. (2003), Etyka seksualna, Wydawnictwo Uniwersytetu Kardynała Wyszyńskiego, Warszawa. 
Deklaracja Praw Seksualnych Człowieka, http://www.worldsexology.org/wp-content/uploads/2013/08/DSR-Polish.pdf.

Gumienny B. (2016), Funkcjonowanie dorostych osób z głębszą niepetnosprawnością intelektualna, „Niepełnosprawność - zagadnienia, problemy, rozwiązania”, nr 3(20).

Imieliński K. (1986), Zarys seksuologii i seksiatrii, Państwowy Zakład Wydawnictw Lekarskich, Warszawa.

Kamińska M., Kierzkowski K. (2016), Seksualność osób niepetnosprawnych intelektualnie - wybrane problemy, „FIDES ET RATIO”, nr 1(25).

Karwacka M. (2006), Stereotypy w myśleniu o seksualności osób z niepetnosprawnościa intelektualna [w:] Poznańska pedagogika specjalna. Tradycje - osiagnięcia - perspektywy rozwoju, W. Dykcik, A. Twardowski (red.), Wydawnictwo Naukowe Uniwersytetu im. Adama Mickiewicza, Poznań.

Kijak R. (2016), Dorośli z głębsza niepetnosprawnościa intelektualna jako partnerzy, małżonkowie i rodzice, Wydawnictwo Naukowe Uniwersytetu Pedagogicznego, Kraków.

Kijak R. (2013), Wprowadzenie w problematykę seksualności osób z niepetnosprawnościa - między teorią a empiria [w:] Seksualność- niepetnosprawność-rzeczywistość, R. Kijak (red.), Instytut Rozwoju Służb Społecznych, Warszawa.

Kościelska M. (2014), Niechciana seksualność. O ludzkich potrzebach osób niepełnosprawnych intelektualnie, Wydawnictwo Czarna Owca, Warszawa.

Kowalski J.A. (2011), Homo eroticus, Wydawnictwo IBS, Opole.

Otrębski W., Czusz A. (2013), Osoby z niepetnosprawnościa intelektualna wobec wtasnej seksualności [w:] Seksualność - niepetnosprawność - rzeczywistość, R. Kijak (red.), Instytut Rozwoju Służb Społecznych, Warszawa.

Parchomiuk M. (2009), Edukacja seksualna osób z niepetnosprawnościa intelektualnq, "Człowiek - Niepełnosprawność - Społeczeństwo", nr 1(9).

Szymczak M. (red.) (1992), Stownik Języka Polskiego, Warszawa PWN. 